\begin{tabular}{lll}
\hline Missio Ecclesiae & INSTITUT \\
ISSN 2086-5368 (Print) & INJIL \\
ISSN 2086-5368 (Online) & INDONESIA \\
https://jurnal.i3batu.ac.id/index.php/me & \\
Vol.9, No.2, pp.45 -65, 2020 &
\end{tabular}

\title{
Model Business For Kingdom Berdasarkan Kisah Para Rasul 18:1-4 Dalam Mengembangkan Sinode Gereja Kristen Parousia
}

\author{
Hendra Rey ${ }^{a}$, Gunaryo Sudarmanto ${ }^{b}$ \\ ${ }^{a}$ Sinode Gereja Kristen Parousia, (gk.parousia@gmail.com) \\ ${ }^{b}$ Institut Injil Indonesia, (revgsudarmanto@gmail.com)
}

\section{INFO ARTIKEL}

Sejarah Artikel:

Diterima :

02 Oktober 2020

Direvisi :

23 Oktober 2020

Disetujui:

30 Oktober 2020

Dipublikasi:

30 Oktober 2020

Kata Kunci:

Model, Business For

Kingdom,

Mengembangkan,

Gereja.

Keywords:

Model, Business For

Kingdom, Developing,

Church

$-\cdots-\cdots-\cdots$

\begin{abstract}
ABSTRAK
Tujuan utama dari penelitian ini adalah untuk memahami secara obyektif mengenai hamba-hamba Tuhan yang mengabdi dan melayani Tuhan melalui pelayanan gerejawi, namun juga melakukan bisnis berdasarkan Kisah 18: 1-4 di Sinode Gereja Kristen Parousia. Penelitian ini merupakan penelitian kualitatif naturalistik dengan menggunakan studi pustaka-eksplanatori.

Dari penelitian literatur tentang Business for Kingdom Model, peneliti membaca dan menginterpretasikan buku tekstual tentang topik ini untuk mendapatkan makna dari teks Kisah Para Rasul 18:1-4. Dan analisis data penelitian lapangan Model "Business for Kingdom" di Sinode Gereja Kristen Parousia dengan menggunakan paradigma kualitatif naturalistik, ditemukan bahwa semua informan memiliki komitmen yang kuat untuk mengabdi kepada Tuhan dan menjalankan bisnis untuk menunjang kebutuhan finansial dan memberdayakan dan melestarikan jemaat yang dilayani tetapi kurang memahami tentang manajemen bisnis sambil tetap mengabdi kepada Tuhan. Namun, ada juga kendala dan hal negatif yang muncul seperti; tidak memiliki pengalaman bisnis, kesulitan membagi waktu, fokus pada prioritas pelayanan yang berubah dan sebagainya.

Peneliti menyarankan kepada Sinode Gereja Kristen Parousia untuk memberikan pendidikan, pelatihan dan pendampingan yang memadai bagi para hamba Tuhan yang akan dikirim ke lokasi-lokasi perintis agar dapat menjalankan usaha kecil dengan baik dan sukses sebagai strategi penanaman dan pengembangan gereja. Hal ini penting untuk visitasi, komunikasi dan pendampingan agar terlaksana dengan baik dan memberikan bantuan pelayanan agar hamba-hamba Tuhan tidak bergumul sendiri.
\end{abstract}

\section{ABSTRACT}

The main purpose of this research is to understand and objectively the servants of God who serve and also do business based on Acts 18: 1-4 at the Sinode Gereja Kristen Parousia. This research is a qualitative naturalistic research using literature-explanatory study.

From the literature research on the Business for Kingdom Model, researchers read and interpret textual books on this topic to get meaning. And the analysis of field research data on the "Business for Kingdom" Model at the Sinode Gereja 
Kristen Parousia using a naturalistic qualitative paradigm, it was found that all informants had a strong commitment for serving God and running a business to support their financial needs and empowering and preserving the congregation but did not quite understand about business management while still serving the God. However, there were also obstacles and negative things that could arise such as; do not have business experience so they need good coaching, training and mentoring, difficulty dividing time, focus on service priorities and so on.

The researcher suggests to the Sinode Gereja Kristen Parousia for providing sufficient education, training and mentoring for servants of God who will be sent to pioneering locations so that they can run small businesses well and successfully as a strategy for church planting and development. It is important for visitations, communication and mentoring so that they are carried out properly and providing assistance for services so the servants of God do not struggling on their own.

\section{PENDAHULUAN}

Krisis ekonomi yang dihadapi oleh Indonesia pada tahun 1997 didahului dengan jatuhnya nilai rupiah terhadap dolar Amerika yang berpengaruh pada perekonomian sehingga terjadi resesi ekonomi. Hal ini memberikan cambuk untuk mempelajari dan menganalisa suatu pertumbuhan ekonomi dengan kekuatan struktur sehingga bisa tetap bertahan dalam keadaan apapun juga.(Anggraini, Dewi dan Nasution 2013) Ketika krisis ekonomi melanda dunia, tentunya secara langsung memperburuk keadaan ekonomi Indonesia. Data yang disajikan oleh Badan Pusat Stastistik memperlihatkan informasi bahwa, "setelah krisis ekonomi jumlah Usaha Mikro Kecil Menengah tidak mengalami penururnan, melainkan meningkat pertumbuhannya, dari delapan puluh lima juta sampai seratus tujuh juta pekerja hingga tahun 2012. Pada periode tersebut, ada sekitar 56.539.560 unit atau sekitar 99,99\% pengusaha di Indonesia. Sisanya sekitar 4.968 atau sebesar 0,01\% unit usaha berskala besar."(Stastistik 2016)

Kenyataan ini memperlihatkan bahwa Usaha Mikro Kecil Menengah (selanjutnya ditulis UMKM) merupakan suatu bentuk usaha yang sangat produktif layak untuk dikembangkan karena dapat mendukung pertumbuhan ekonomi di Indonesia dan berpengaruh pada sektor yang lain. Segala kesuksesan yang diraih memiliki kelemahan yang harus segera diatasi. Kelemahan yang dihadapi para pengusaha UMKM dalam mengusahakan kenaikan kemampuan usaha sangat sulit karena berkaitan dengan indikator yang lainnya, seperti; kekurangan permodalan dari segi jumlah maupun sumbernya, ketidakmampuan dalam hal manajemen dan keterampilan dalam mengorganisir dan juga keterbatasan dalam bidang pemasaran.

UMKM mampu menjadi solusi bagi penanggulangan kemiskinan di Indonesia, karena memiliki kapasitas yang cukup baik dalam berkontribusi untuk menyerap tenaga kerja, lebih dari 99,4\% tenaga kerja dan memberikan sumbangsih bagi Produk Domestik Bruto atau yang disingkat PDB sekitar 30\%.(I. D. K. R. Ardina, I. A.Brahmayanti 2010) Dengan demikian usaha untuk memajukan dan mengembangkan sektor UMKM akan dapat merekrut sejumlah tenaga kerja yang banyak sehingga meningkatkan kesejahteraan para tenaga kerja jadi bisa mengurangi jumlah pengangguran dan berdampak pada pengentasan kemiskinan.

Undang-Undang No. 20/2008 mengatur mengenai UMKM di Indonesia menyebutnya sebagai perusahaan kecil yang dimiliki dan dikelola oleh sekelompok kecil atau seseorang dengan jumlah kekayaan dan perolehan pendapatan tertentu.(Hidayah 2018). Pengelola usaha adalah orang yang tidak bekerja pada sektor pemerintah contohnya; pedagang, 
pengusaha, dan individu yang mencari nafkah di perusahaan swasta, sedangkan wirausahawan adalah individu yang memiliki usaha sendiri dan merupakan orang yang berani membuka kegiatan produktif yang mandiri.(Yaghoobi, Salarzehi 2010). Mengacu pada pengertian wirausahawan tersebut, di dalam Alkitab sudah menulis mengenai beberapa pengusaha seperti Lidia, wanita penjual kain ungu dari Tiatira' di propinsi Asia (Kis.16:14), yang ditemui Paulus di Filipi di Makedonia.

Bukti Alkitab tentang kehidupan dan pelayanan Rasul Paulus termasuk pengakuan apresiatif dari beberapa wanita abad pertama sebagai pemimpin komunitas dan sebagai rekan kerja dalam Injil dengan Paulus, Priskila dan Akwila di antara mereka. Bertentangan dengan pendapat kontemporer yang sering mencirikan Paulus sebagai musuh wanita, kitab suci melukiskan gambaran inklusivitas yang signifikan dalam perkembangan awal Kekristenan. Melalui contoh Priskila dan Akwila, yang dibuktikan dalam Kisah Para Rasul dan dalam pelayanan Paulus dan menemukan Priskila dan Akwila sebagai saksi iman yang luar biasa dalam gerakan Kristen awal.(McCarty 2012). Pelayanan tent-maker tidak hanya mengurangi beban keuangan gereja, tetapi juga menyediakan cara bagi orang Kristen untuk melakukan kontak dengan orang-orang di tempat kerja.(Deffinbaugh n.d.) "Tent-making ministry" tidak hanya mengurangi beban keuangan gereja, tetapi juga menyediakan cara bagi orang Kristen untuk melakukan kontak dengan orang-orang di tempat kerja Rasul Paulus bertahun-tahun lebih awal dari waktunya.(Deffinbaugh n.d.). Hal inilah yang menjadi stimulan bagi peneliti untuk mengetahui efektivitas Business For Kingdom yang dijalankan oleh Sinode Gereja Kristen Parousia melalui program UMKM (Usaha Mikro Kecil Menengah) yang harus dikerjakan oleh setiap tenaga yang bergabung sebagai tenaga perintis gereja.

Jadi setiap hamba Tuhan dalam lingkungan Sinode Gereja Kristen Parousia wajib melakukan usaha kecil yang disebut Business For Kingdom (BFK) untuk menunaikan tugas misi memberdayakan dan mensejahterakan sekaligus sebagai platform tenaga perintis memasuki satu lokasi atau daerah di Indonesia, serta sebagai pendukung tingkat kesejahteraan tenaga perintis gereja. Sinode Gereja Kristen Parousia adalah gereja Presbiterial Sinodal di Indonesia yang secara legal baru dimulai pada tahun 2014 dan secara praktis baru dimulai pada 2016. Pada Sinode Gereja Kristen Parousia mengharuskan semua tenaga perintis (Hamba Tuhan) untuk melakukan Mikro Bisnis atau Usaha Mikro Kecil Menengah. Usaha Mikro Kecil Menengah mengacu pada usaha ekonomi produktif milik perorangan atau badan usaha sesuai dengan kriteria yang ditetapkan oleh Undang-undang nomor 20 tahun 2008.

Usaha Mikro Kecil Menengah yang hendak dijalankan oleh Sinode Gereja Kristen Parousia, didefinisikan sebagai “Business for Kingdom” untuk menjalankan visi misi gereja yakni; menjadi gereja rumah yang mempertobatkan, mencerdaskan, memberdayakan dan mensejahterakan. Pengertian Bussines For Kingdom itu untuk menekankan bahwa bisnis yang dijalankan tidak semata-mata untuk kepentingan pribadi maupun kelompok namun tujuan utamanya adalah memuliakan Tuhan, khususnya dalam mengembangkan Kerajaan Allah melalui Sinode Gereja Kristen Parousia.

Program Bussines For Kingdom dirancang setelah penulis melihat beberapa permasalahan yang timbul dalam upaya perintisan gereja terutama di darerah-daerah; (Penulis sebelumnya memimpin Yayasan Misi, melakukan misi di beberapa propinsi di dalam mapun luar negeri). Pertama, gereja induk atau gereja pendamping tidak mendukung dana secara penuh untuk kesejahteraan tenaga perintis dan kecukupan melakukan perintisan gereja. Ada banyak tenaga perintis tidak mendapat dukungan dana yang memadai, jauh dari upah minimum regional yang berlaku di daerah-daerah di Indonesia. Kedua, di daerahdaerah yang tidak mudah menerima kekristenan banyak tenaga perintis gereja menggunakan platform supaya lebih mudah diterima. Platform yang digunakan umumnya adalah usaha kecil baik itu buka toko kelontong, ternak beberapa ekor sapi, kambing babi atau unggas, 
berkebun, bertani dan sebagainya. Hal ini juga dapat disesuaikan dengan konteks daerah setempat, misalnya di daerah Sumba, dilakukan peternakan babi atau sapi. Dalam pengamatan penulis, kurangnya skill atau perlengkapan menyebabkan kebanyakan di antara mereka akhirnya hanya sekedar platform tetapi secara ekonomi mengalami kerugian. Beberapa di antaranya bisa berhasil dalam usaha kecil mereka tetapi pelayanan tidak berkembang bahkan akhirnya tidak lagi fokus kepada perintisan gereja dan menghentikan usaha perintisan gereja. Ketiga, tenaga perintis gereja memiliki tingkat kesejahteraan yang memadai namun banyak jemaat yang hidup di bawah garis kemiskinan. Sudah banyak upaya membantu meningkatkan ekonomi jemaat tetapi tak jarang terjadi kegagalan karena kurangnya pembinaan, pelatihan dan kontrol yang dilakukan.

Bertolak dari latar belakang di atas, maka akan membahas sebuah artikel dengn judul

Model Business For Kingdom Berdasarkan Kisah Para Rasul 18:1-4 Dalam Mengembangkan Sinode Gereja Kristen Parousia.

\section{Kajian Literatur}

Kata bisnis selalu maknai sebagai usaha untuk memperoleh keuntungan melalui jual beli yang dilakukan oleh perorangan, kelompok atau keluarga, koperasi atau perusahaan secara konvensional maupun online. Bisnis merupakan sebuah strategi, untung dan rugi, perputaran uang, dengan waktu yang panjang tetapi juga bisa singkat. Bisnis merupakan sebuah pekerjaan alternatif yang bisa dikerjakan oleh seseorang untuk mendapat keuntungan demi menjalankan kehidupan.

\section{Pengertian Bisnis}

Istilah bisnis dari kata business yang di dalam bahasa Indonesia memliki tiga pengertian yaitu, perusahaan, urusan, dan usaha. Kata business berasal dari kata busy atau sibuk yaitu seseorang atau sekelompok orang yang mengerjakan sesuatu yang dapat menghasilkan keuntungan.(Anon n.d.) Boone dan Kurtz mengartikan bisnis sebagai, "tujuan dari sebuah aktivitas untuk memperoleh laba atau perusahaan yang memproduksi barang serta jasa yang dibutuhkan oleh sebuah sistem ekonomi. Bisnis yang menghasilkan barang contohnya otomotif, computer dan smartphone, tekstil, bahan makanan dan sebagainya. Bisnis yang memproduksi jasa seperti asuransi, penginapan, salon, konser musik.'(Boone, Louis E dan Kurtz 2002) Sedangkan menurut Saydam, "bisnis merupakan semua kegiatan yang dilakukan seseorang atau lebih, yang terorganisir dengan tujuan memperoleh keuntungan melalui penyediaan produk yang dibutuhkan oleh masyarakat."'(Saydam 2006) Bagaimana membuat suatu produk dan jasa yang berguna dan dibutuhkan orang lain atau konsumen lalu kemudian dijual, atau memasarkan suatu produk agar beroleh keuntungan..

Jadi bisnis dapat diartikan sebagai sebuah usaha untuk mengelola produk barang dan jasa guna memperoleh keuntungan untuk menghidupi diri, keluarga, organisasi dan lingkungan, melalui kolaborasi usaha antara ide, tenaga kerja, material, modal, keterampilan dalam melakukan inovasi yang kreatif sampai menghasilkan suatu jasa dan produk yang dapat dijual dan memberikan manfaat untuk orang lain.

\section{Pengelolaan Bisnis}

Kepentingan dan keterlibatan dalam pengelolaan bisnis yang melibatkan sumber daya manusia dalam bisnis digolongkan menjadi menjadi: Pertama, Pemilik Modal. Pemodal atau pemilik modal adalah orang yang mengusahakan dan menyediakan dana untuk kelancaran operasional dan aktivitas bisnis. Kedua, Manajer. Manajer adalah orang yang bertanggung jawab secara operasional untuk mengelola dan menjalankan bisnis secara operasional hingga mencapai tujuan yang diinginkan oleh pemilik modal. Ketiga, Tenaga kerja. Untuk 
memenuhi kebutuhan dan keinginan konsumen akan produk yang baik dan berkualitan dibutuhkan pelaksana proses produksi yaitu tenaga kerja. Keempat, Konsumen. Hasil usaha bisnis yang dunakan oleh pengguna disebut konsumen adalah kelompok yang menggunakan produk ataupun jasa yang ditawarkan oleh organisasi bisnis.(Alteza 2011)

Adanya organisani bisnis memberikan banyak manfaat dan kelebihan dalam menjaga kualitas produk, peluang bisnis dan informasi kerjasama dengan lembaga atau perusahaan lainnya. Dalam persaingan, organisasi bisnis memiliki pengaturan dan mengantisipasi persaingan yang tidak sehat. Seperti persaingan dalam memainkan harga dan stock barang supaya harga produksi melambung dan mendapat keuntungan secara sepihak, juga hal lain yang mengatur perputaran bisnis agar berjalan dengan baik.(Saydam 2006)

Ada hal-hal yang perlu dipertimbangan untuk membentuk suatu usaha bisnis yaitu:

a. Jumlah dana yang diperlukan untuk melakukan suatu usaha

b. Pertanggungjawaban usaha apabila terjadi kerugian atau kebangkrutan yang merupakan resiko dari sebuah usaha bisnis

c. Kemampuan pemilik usaha bisnis dalam pengawasan usaha

d. Keahlian untuk merencanakan, mengendalikan, dan mengawasi usaha

e. Kemampuan untuk menyediakan waktu yang cukup untuk menjalankan usaha dengan baik.(Saydam 2006)

\section{Manajemen}

Kata manajemen dari "maneggiare" (Bahasa Itali) yang memiliki makna "mengendalikan,"(Setiawan n.d.). Bahasa Perancis kemudian mengadopsi kata manajemen dari bahasa Inggris menjadi ménagement, dari kata dasar "to manage" atau seni melaksanakan dan mengatur, mengurus atau mengelola.(Setiawan n.d.)

Manajemen membutuhkan tiga unsur penting yaitu: pandangan, pengetahuan teknis, dan komunikasi. Dan juga unsur-unsur manajemen lainnya seperti hubungan antarmanusia atau kemampuan interpersonal.(Nyoto 2019) Stoner mengartikan manajemen sebagai, proses perencanaan, pengorganisasian, memimpin dan mengendalikan upaya anggota organisasi dan menggunakan semua sumber daya organisasi lainnya untuk mencapai tujuan organisasi yang telah ditetapkan.(Stoner 1982) Dengan demikian manajemen terdiri dari proses kepemimpinan, perencanaan, organisasi, dan pengawasan terhadap usaha-usaha anggota organisasi dan penggunaan semua sumber organisasi demi mencapai tujuan organisasi yang diinginkan. Manajemen adalah suatu bidang pengetahuan (ilmu) yang berusaha memahami mengapa dan bagaimana orang bekerja sama.

Menurut Kats, "Seorang manajer harus memiliki tiga keahlian, yaitu kompetensi secara konseptual, sosial, dan teknikal."(Nyoto 2019) Pertama, Kemampuan konsep, kemampuan untuk berpikir dan menggagas situasi yang abstrak dan melihat organisasi sebagai suatu kesamaan dan hubungannya dengan sub-sub unit, serta menggambarkan bagaimana organisasi dapat masuk dalam lingkungan tertentu. Kemampuan konsep ini dimiliki oleh manajemen puncak. Kedua, Kemampuan sosial (manusiawi) yaitu kemampuan untuk bekerja bersama orang lain baik secara individual maupun dalam suatu kelompok. Kemampuan sosial ini dimiliki oleh manajemen menengah. Ketiga, Kemampuan teknikal. Kemampuan ini mencakup pengetahuan dan keahlian dalam bidang tertentu, seperti keuangan, rekayasa, produksi, dan komputer. Kemampuan ini ada pada manajemen tingkat rendah.(Wibowo 2009)

Manajemen merupakan sebuah proses yang terdiri dari serangkaian kegiatan, seperti perencanaan, pengorganisasian, pengarahan dan pengendalian atau pengawasan, yang dilakukan untuk menentukan dan demi mencapai tujuan secara efesien dan efektif.(Wibowo 2009) Pertama, Perencanaan. perencanaan matang mengenai kegiatan-kegiatan sebelum dilaksanakan dengan memakai beberapa metode, logika, berdasarkan data yang mendukung, dalam pengambilan keputusan secara ilmiah untuk mengkaji kekuatan dan kelemahan 
organisasi, menentukan kesempatan dan ancaman, menetapkan strategi, kebijakan, dan program. Kedua, Pengorganisasian. mengkoordinasikan sumber-sumber daya (resources) yang terdiri dari manusia, peralatan, bahan, waktu dan uang. Proses sangat menentukan keefektifan pencapaian tujuan sebuah organisasi. Penentuan fungsi, hubungan, dan struktur dilakukan dalam tahap ini. Fungsi berupa tugas-tugas yang dibagi dalam bentuk garis, untuk staf, dan fungsional, dengan hubungan yang meliputi tanggung jawab dan wewenang. Sedangkan untuk struktur terbagi menjadi bentuk vertikal atau horizontal.

Ketiga, Pengarahan. Memberikan arahan dan prosedur kerja kepada karyawan supaya bisa melakukan pekerjaan dengan cara yang baik, dengan iklim kerja yang kondusif demi terlaksananya kegiatan. Keempat, Pengawasan. Memastikan bahwa setiap aktivitas berjalan baik dan perbaikan apabila yang dikerjakan tidak sesuai dari tujuan organisasi yang diharapkan dapat menjamin kelangsungan organisasi untuk meraih tujuannya dan keefektifan manajemen diharapkan dapat terukur. Kelima, Efisiensi. Efisiensi berkaitan dengan masukan dan keluaran. Jika harga keluaran lebih besar dari masukan, maka terjadi peningkatan efesiensi. Sumber masukan terdiri dari manusia, uang, dan peralatan. Jadi, manajemen berupaya untuk meminimalkan biaya sumber daya (masukan) tersebut agar menghasilkan keluaran yang optimal. Dari sudut pandang ini, efesiensi sering dikenal sebagai "melakukan secara tepat" (do the things right), atau tidak memboroskan sumbersumber. Keenam, Efektivitas. Setiap kegiatan yang dilakukan diharapkan mampu mencapai tujuan organisasi. Pada saat seorang manajer mencapai sasaran organisasi, maka bisa dikatakan organisasi tersebut berhasil guna (efektif), sehingga efektivitas disebut sebagai "melakukan hal-hal dengan tepat" (do the right things).(Wibowo 2009)

\section{Bisnis Dalam Perspektif Teologis}

Istilah Ibrani yang dipakai adalah kabash yang terdapat di dalam Kejadian 1:26,28 memiliki arti berkuasa atau radah (Strong 1990). Kata "berkuasalah" memiliki arti bahwa manusia menguasai seluruh ciptaan Tuhan. Tetapi hal ini tidak berarti manusia diberikan kesempatan untuk merusak ciptaan Allah. Maksud Allah menciptakan manusia adalah agar manusia dapat mengusahakan dan memelihara apa yang sudah Tuhan diciptakan, sebab hanya manusia yang memiliki kemampuan untuk melakukan kedua hal itu; ciptaan Tuhan yang lain tidak diperlengkapi dengan akal atau pikiran untuk mengupayakan dan memelihara apa yang telah diciptakan Tuhan. Kejadian 2:15). (Zuck 2010). Menurut Hall dan Burton, "Calvin menegakkan pandangan bahwa orang bertanggung jawab untuk memenuhi kebutuhannya sendiri dan para tanggungannya...Calvin menerapkan kata-kata 1 Timotius 5:8 secara umum, mengklaim bahwa orang-orang yang tidak memelihara keluarganya sendiri tidak memiliki "kesalehan kepada Allah." (Burton 2019) Perintah yang Tuhan berikan kepada manusia untuk mengusahakan mencakup tugas untuk mencari makanan bagi kebutuhan manusia itu sendiri; dan di dalam perintah untuk memelihara ada perintah untuk menjaga kelestarian ciptaan Tuhan. Calvin menyatakan, walaupun ada "cara kerja yang berbeda-beda," tetapi setiap orang seharusnya membantu, "masyarakat manusia dengan industrinya, baik dalam mengatur keluarganya, atau dengan mengurus urusan publik atau privat, atau dengan konseling, atau dengan pengajaran, atau dengan jalan lain ... yang tidak termasuk berpangku tangan."(Calvin 1979).

Kedua, Bisnis sebatas kegiatan usaha atau kerja tapi juga pelayanan (Kej. 3:17-19; 2 Tes.3:10). Bisnis merupakan pekerjaan dan harus dipelajari serta dilakukan sesuai pengajaran Alkitab.(Ruffner 2004) Rasul Paulus member nasehat kepada jemaat di Tesalonika agar bekerja (2 Tes. 3:10b). Karena bekerja adalah merupakan anugerah dan panggilan, maka sudah seharusnya orang Kristen bekerja dengan keras, cerdas, ikhlas, dan tuntas.(Sandison 2013)

Ketiga, Bisnis yang dilakukan hendaknya digunakan untuk kemuliaan Tuhan (Mazmur 150; Roma 11:36). Manusia hendaknya memuliakan Allah sebagai pemberi berkat 
melalui bisnis yang dilakukan. Hal ini merupakan tanda ucapa syukur manusia kepada Allah. Karena apa yang sedang diusahakan oleh manusia merupakan berkat dari Tuhan, dan Tuhan sendiri yang memberikan mandat untuk menguasai dan melestarikan serta memberikan kecerdasan, kemampuan, bakat dan ketrampilan untuk melakukan mengelola pekerjaannya, termasuk kegiatan bisnis. Sehingga dalam usaha bisnis yang dilakukan, manusia harus mengerjakan dengan sebaik-baiknya dan bertanggung jawab kepada Allah saja.

Keempat, menjadi terang dan garam (Mat. 5:13-14). Tuhan menghendaki agar orang percaya melakukan pekerjaan-pekerjaan yang baik di semua aspek kehidupan, termasuk saat melakukan bisnis.

Kelima, bisnis harus dilihat sebagai alat bukan tujuan. Orang Kristen hendaknya memahami bahwa bisnis hanya memiliki fungsi sebagai alat agar hidup manusia dapat terpelihara. Bisnis bukanlah segalanya dan tidak boleh menjadi tujuan hidup manusia. Hal ini sudah dilakukan oleh Rasul Paulus, yaitu dengan berjualan tenda sebagai alat untuk mendukung pelayanan dan kebutuhan hidupnya tanpa membebani kehidupan keuangan jemaat. (Kis.18:1-3).(Stamps 1995).

\section{Etika Bisnis Kristen}

Etika Kristen merupakan aplikasi orang percaya terhadap nilai-nilai Alkitabiah dalam pengambilan keputusan.(Hill 2001) John Frame menyajikan formulasi etika Kristen yang sistematis dengan cara pertama-tama menentang bentuk-bentuk etika non-Kristen, kemudian mengembangkan pemahaman Kristen berdasarkan penerapan Sepuluh Perintah Allah pada beragam masalah etika.(Frame 2008) Dengan demikian titik berangkat dari cara berpikir etika Kristen adalah iman kepada Tuhan yang telah menyatakan diri di dalam Tuhan Yesus Kristus dan berdasarkan pada Alkitab yang adalah firman Tuhan yang tertulis.

Etika Kristen adalah respon terhadap kasih Allah yang menyelamatkan orang percaya (1 Yoh. 4:19). Sedangkan kehidupan etis merupakan cara hidup dalam Tuhan yang juga terimplementasi dalam persekutuan dengan sesama. Jadi orang percaya, termasuk di dalamnya Pengusaha Kristen dilarang untuk melakukan segala sesuatu yang bertentangan dengan hukum kasih Allah dan Firman Allah (Efesus 2:10). Dengan demikian, di dalam kekristenan, bisnis tidak dapat dilepaskan dari tanggung jawab kepada Tuhan. Orang Kristen perlu menyadari bahwa Tuhan peduli pada anak-anakNya serta ingin memberkati usaha atau bisnis anak-anakNya (Ul. 28:8-11).

Hal yang perlu diperhatikan di antaranya adalah dalam menerapkan bunga dan riba yang tinggi. Riba dapat didefiniskan dalam dua cara, Pertama, mengenakan bunga atas pinjaman pada setiap saat; atau kedua, mengenakan persentase bunga yang tinggi sehingga dapat berarti mencuri atau memeras orang miskin.(Burton 2019) Uang bukan saja mengecewakan dan menipu serta mencekik seseorang; uang juga mempunyai kuasa untuk membuat manusia berbahaya bagi manusia lain.(Piper 2019) Lukas berkata tentang golongan pemimpin agama yang paling berpengaruh pada masa Yesus bahwa mereka adalah pencinta uang: "Orang-orang Farisi, hamba-hamba uang itu, dan mereka mencemooh Dia.", (Lukas 16:14). Dan cinta akan uang mengubah mereka menjadi orang tamak. $\alpha \rho \pi \alpha \gamma \eta$ (harpagē) bukanlah kata yang lazim tentang rampasan (keserakahan) dan ketamakan yaitu $\pi \lambda \varepsilon_{0 v \varepsilon} \xi^{\prime} i \alpha$ (pleonexia). Ini artinya merampas dan merampas biasanya melibatkan tindakan mencari untuk mengambil milik orang lain. (Piper 2019) Bagi seorang hamba Tuhan yang berbisnis, hendaknya berusaha menjadi teladan pengusaha Kristen, menginspirasi kewirausahaan, membawa relevansi bisnis pada pelayanan dan menambah nilai pada aspek operasional gereja yang dilayani. Alkitab mengajarkan untuk "menjauhkan diri dari segala kejahatan" (1 Tes. 5:22). Seorang hamba Tuhan yang melakukan bisnis harus memastikan bahwa gereja memiliki tata kelola perusahaan yang baik dan tidak ada konflik kepentingan antara gereja dan bisnis yang dilakukan. 
Setiap keputusan, strategi dan kebijakan harus disaring melalui seperangkat aturan yang diterapkan sendiri yang disebut nilai-nilai alkitabiah. Setiap tujuan dan sasaran harus mencapai tujuan ilahi. Bahkan prosesnya harus memuliakan Tuhan dan tujuan tidak harus membenarkan cara.(How n.d.) Meskipun bisnis tidak jelas bersifat 'spiritual', seorang hamba Tuhan harus senantiasa ingat dan sadar bahwa suatu hari harus memberikan pertanggungjawaban apa yang dilakukannya kepada Tuhan. Hati dan motivasi harus diatur oleh rasa takut akan Tuhan. Prioritas utama adalah gereja, sedangkan bisnis adalah hal sekunder dan saling melengkapi. Gunakan bisnis untuk membangun atau memberkati gereja. Jangan gunakan gereja untuk membangun atau memberkati bisnis. Tujuan utama pelayanan dan bisnis adalah Kristus, keuntungannya yang diperoleh untuk tujuan-Nya dan umat-Nya. Jadi esensi seorang hamba Tuhan yang melakukan bisnis adalah keserupaan dengan Kristus.

\section{Hamba Tuhan dan Bisnis}

Berdasarkan pengertian bisnis dan kajian Alkitabiah, perlu motivasi yang jelas untuk melakukan pekerjaan sampingan sebagai pebisnis. Hamba Tuhan yang berbisnis tidaklah salah karena di dalam Alkitab dipaparkan mengenai tokoh-tokoh di Alkitab yang melakukan bisnis, baik hamba Tuhan yang melakukan bisnis tetapi ada juga pebisnis yang melakukan pelayanan. Hal tersebut bukanlah sesuatu yang salah karena baik pebisnis maupun hamba Tuhan adalah orang-orang yang memiliki potensi dan mau mengembangkan diri namun didasari dengan sikap dan motivasi yang benar yaitu yang sesuai kehendak Tuhan dan memuliakan Tuhan.(Tan 2010)

Hal ini sangat mendasar, karena seorang hamba Tuhan dituntut untuk bijak menavigasi dua dunia yang berdampingan ini. Secara tradisional, selalu lebih mudah dan sederhana untuk memisahkan antara sekuler dan sakral. Sehingga hamba Tuhan tidak harus berurusan dengan persepsi negatif. Ada sentimen umum bahwa bisnis dan gereja adalah campuran yang mencurigakan. Anggapan tersebut harus dilihat sebagai tantangan untuk semakin meningkatkan standar jabatan seorang pendeta dan menyanggah kesalahpahaman bahwa 'semua' pendeta itu jahat. Ada banyak pendeta yang baik, saleh, tulus dengan integritas.(How n.d.)

Dengan demikian, makna Business For Kingdom yang perlu dilakukan oleh seorang hamba Tuhan yang berbisnis adalah:

1. Hadapi dunia bisnis dengan optimisme yang dibimbing oleh rasa takut akan Tuhan, sambil menavigasi dunia gereja dengan iman yang diiringi oleh hikmat. Kedua bidang yang digeluti, secara internal, hati dan motivasi seorang hamba Tuhan harus diatur oleh sikap rasa takut akan Tuhan. Secara eksternal, kata-kata dan perbuatan hamba Tuhan harus dalam oleh kehati-hatian, sehingga tidak mengesampingkan pelayanan atau menelantarkan bisnis.

Seorang hamba Tuhan yang berbisnis harus menunjukkan kepada jemaat atau orang lain perbedaan besar yaitu, menghasilkan uang dari dunia untuk diberikan ke gereja bukan menghasilkan uang dari anggota gereja.(How n.d.)

2. Jangan pernah memonetisasi gereja. Kisah di dalam Alkitab yang tertulis di dalam Lukas 19:45, beberapa orang mencoba untuk mengkomersialkan gereja, dan Yesus datang kembali dengan cambuk dan membalik meja-meja penukar uang di bait suci. Dalam Kisah Para Rasul 8:17-24 menjelaskan mengenai Simon si tukang sihir yang melihat kuasa Roh Kudus dan dia ingin menghasilkan uang. Ayat 20, Petrus

menegurnya secara keras dan tegas, "Binasalah kiranya uangmu itu bersama dengan engkau, karena engkau menyangka, bahwa engkau dapat membeli karunia Allah dengan uang(How n.d.).

Menurut Tan, hamba Tuhan penuh waktu yang berbisnis tidak ada masalah, asalkan Pertama, tidak meninggalkan panggilan dan pelayanannya karena kesulitan ekonomi, namun harus kreatif dalam mengembangkan diri dan keahliannya dalam usaha yang 
sesuai konteks pelayanannya. Kedua, dapat memenuhi kebutuhan hidupnya sendiri dan membantu jemaat dan sesamanya.

3. Bisnis yang Tuhan percayakan harus dijalankan secara bertanggungjawab. Walaupun bisnis bukan yang prioritas bagi seorang hamba Tuhan, tetapi hendaknya bisnis dapat dijalankan secara profesional karena bisnis adalah milik Tuhan.(Tan 2010)

4. Menata waktu dengan baik antara bisnis dan pelayanan, sehingga memberikan hasil yang berkualitas dalam bisnis dan juga pelayanan. Kelima, Memiliki partner dalam pelayanan dan bisnis untuk membantu agar pelayanan tidak terbengkalai (Tan 2010). Dengan demikian, seorang hamba Tuhan yang menjalankan pelayanan dan bisnis harus ada keseimbangan. Memang kedua bidang yang dilakukan adalah pemberian yang Tuhan percayakan, tetapi harus senantiasa memprioritaskan pelayanan sebagai yang utama. Seorang hamba Tuhan harus melakukan untuk kemuliaan Tuhan karena bisnis itu adalah milik Tuhan dan manusia hanya sebagai pengelola saja.

\section{Model Business for Kingdom Berdasarkan Kisah Para Rasul 18:1-4}

Kata Kisah mengacu pada serangkaian sejarah pelayanan yang dilakukan oleh para rasul.(White 1980) Kitab ini menyajikan sebuah hubungan yang jelas dan tidak dapat diabaikan antara catatan mengenai kehidupan Tuhan Yesus dan penafsiran, khotbah dan penerapan dari kata-kataNya dalam tindakan oleh para murid-Nya yang tercatat di dalam Perjanjian Baru.

\section{Analisa Konteks Kisah Para Rasul 18:1-4}

Pada bagian ini, penulis akan menjelaskan mengenai konteks dari Kis.18:1-4, yaitu konteks jauh dan konteks dekat.

\section{Konteks Jauh}

Ketika bangsa Israel menduduki tanah Kanaan, suatu daerah yang subur yang melimpah susu dan madu (Kel. 3:8; Ul. 26:8), bangsa Israel mulai mengelola daerah tersebut bagi pemenuhan kebutuhan ekonomi mereka. Kanaan merupakan tempat perdagangan yang disukai karena letaknya yang strategis karena tepat pada jalur perdagangan utama.

Bangsa-bangsa melakukan bisnis dengan cara tukar-menukar atau barter misalnya minyak zaitun(Yeh. 27:17).(White 1980) Dalam kitab 1 Raja-raja dicatat bahwa Salomo juga terlibat dalam usaha dagang atau bisnis. 1 Raja-raja 4:22-24 mencatat mengenai daerah pertanian dan peternakan yang berada di bawah kekuasaan Salomo. Salomo juga melakukan import bahan untuk bait suci dari negeri-negeri tetangga (1 Raja-raja 9:15). Dalam kitab Yehezkiel menjelaskan mengenai cara-cara berdagang orang Fenisia (Yehezkiel 27:3) dengan barang yang diperdagangkan seperti timah, besi, gading, kaca, kayu, emas, perak, kapas, dan wol.(J.1. Packer 2001)

Di dalam Perjanjian Baru, pengertian istilah "perbuatan baik" yang terdapat pada Efesus 2:10 berasal dari kata Yunani "ergois agathois" yang diterjemahkan "perbuatanperbuatan yang baik". Kata ergo diartikan oleh Thayer sebagai business, employment, that which any one is occupied. That which one undertakes to do, enterprise, undertaking.(Thayer 1997) Sedangkan kata "agathois" dari kata "agathos" untuk menerangkan gagasan yang "baik" sebagai kualitas secara jasmani atau moral.(Strong 1990) Kata agathos bisa diartikan "baik, mulia, patut, terhormat, dan mengagumkan." Jika kemampuan untuk bekerja atau berbisnis merupakan alat untuk mengekspresikan bakat, talenta, dan kemampuan dari kecerdasan yang dianugerahkan Tuhan,(Thayer 1997) maka harus digunakan untuk melakukan pekerjaan-pekerjaan yang baik bagi sesama dan memuliakan Tuhan (Rm. 11:36).

Mengenai usaha, dalam Matius 25:14-30, Tuhan Yesus memberikan perumpamaan mengenai talenta. Matthew Henry berpendapat bahwa, Manusia hanya pekerja, jadi apa pun 
kemampuan dan keunggulan yang manusia miliki, semua itu bukan miliknya, sehingga semua yang dikerjakannya harus dipertanggungjawabkan kepada Tuhan yang memiliki semua harta itu.(Henry 2008) Orang Kristen sejati merupakan seorang pengusaha yang membuat suatu produksi untuk kebaikan orang lain. Seorang pengusaha akan menentukan kegiatan usaha dan bersusah payah mempelajarinya, berusaha keras mengikutinya, mempertaruhkan segala miliknya untuk kemajuan usaha. Seorang pengusaha akan mengesampingkan urusan lain demi kelangsungan usahanya tersebut, dan hidup dari apa yang diperoleh usaha tersebut.(Henry 2008)

\section{Konteks Dekat}

Di dalam konteks dekat, penulis akan menguraikan mengenai konteks sebelum dan sesudah teks yang penulis tentukan yaitu Kis.18:1-4.

\section{Konteks Sebelum Kisah Para Rasul 18:1-4}

Konteks sebelum Kisah Para Rasul 18:1-4, terdapat kelanjutan sejarah perjalanan Rasul Paulus semua pengalaman pelayanan dan penderitaannya yang dialaminya bagi Kristus. Rasul Paulus memulai pelayanan di Filipi, kota pertama yang dikunjunginya. Namun Paulus tidak membatasi pelayanannya hanya pada kota ini. Paulus melanjutkan pelayanan dan pekerjaannya, walupun ia diperlakukan dengan buruk di Filipi. Dan kemudian mengalami penganiayaan di Tesalonika saat memberitakan Injil dan juga di sebuah kota di Makedonia (ay. Kis 17:1-9). Paulus tidak berkecil hati dan mundur dari pelayanan. Hal ini dicatat di dalam 1 Tesalonika 2:2 yang merupakan dalam surat pertamanya kepada jemaat di sini.

Paulus mengajarkan Kitab Suci kepada jemaat dan mereka sepakat untuk menerima Perjanjian Lama. Walaupun ada motivasi yang lain dari jemaat yang diajarkan yang mengira, dengan menerima Kitab Suci, mereka ada alasan untuk menolak Kristus. Tetapi bagi Paulus, hal itu justru menjadi alasan untuk menerima Kristus. Oleh karena itu, agar mereka dapat diyakinkan, Paulus melakukan soal jawab dengan jemaat tersebut.(Henry 1991, 2008) Tujuan Paulus adalah agar melalui perdebatannya, Paulus dapat membuktikan dan memberitakan mengenai Yesus Kristus (Kis.17:3.) Hal yang diajarkan dan ditegaskan oleh Rasul Paulus adalah: Pertama, nubuatan-nubuatan di dalam Perjanjian Lama mengenai Mesias menyatakan Mesias harus menderita, mati, namun akan bangkit. Orang Yahudi menganggap kematian dan penderitaan-Nya merupakan hal yang sangat memalukan. Salib Kristus merupakan batu sandungan bagi orang-orang Yahudi, sebab salib sama sekali bertentangan dengan paradigm yang mereka miliki mengenai Mesias.

Pada ayat 4 tercatat mengenai keberhasilan dari pelayanan Paulus di Tesalonika (Ay. Kis 17:4) sebab ada sebagian orang Yahudi menjadi percaya dan menggabungkan diri dengan Paulus dan Silas, termasuk di dalamnya banyak orang Yunani dan perempuanperempuan terkemuka menerima Injil. Mereka merupakan pemeluk agama Yahudi di pintu gerbang yang yang tidak bisa masuk ke ruang rumah ibadah yang diperuntukkan bagi orang Yahudi.(Henry 1991) Kedua, Paulus mengajarkan bahwa Yesus adalah Mesias. Paulus memberitakan Injil di Berea, orang-orang di sana mau mendengarnya, walaupun kemudian ia disuruh pergi (ay. Kis 17:10-15). Selanjutnya di dalam Kis 17:16-21, Paulus bertanya jawab di Atena, dan ia bersaksi secara kontekstual dan dari pelayanan tersebut banyak orang yang menyembah banyak dewa atau berhala, dituntun untuk percaya Kristus (ay. Kis 17:2231). Di dalam ayat 32-34, memberi penjelasan tentang keberhasilan kotbah Paulus itu.(Henry 1991)

\section{Konteks Sesudah Kisah Para Rasul 18:1-4}


Konteks sesudah Kisah Para Rasul 18:1-4 menjelaskan mengenai kedatangan Paulus ke Efesus dan bertemu dengan Apolos yang merupakan seorang Yahudi, dari Aleksandria di Mesir, namun lahir dari orangtua Yahudi. Apolos dianugerahi talenta yang luar biasa dan sangat bersemangat dalam pelayanan. Apolos sangat mahir berbicara dan pemahaman yang baik terhadap Kitab Suci Perjanjian Lama, karena latarbelakangnya sebagai orang Yahudi. Apolos mampu memahami dan menjelaskan maksud dan arti dari Kitab Suci, serta bagaimana menggunakan dan menerapkannya.

Dia adalah seorang yang bijaksana (Yunani: anēr logios) atau terpelajar (Strong 1990). King James Version menggunakan istilah eloquent yang memiliki arti memiliki kemampuan berpidato yang baik. Apolos juga disebut historiarum peritus karena memiliki keahlian dalam bidang sejarah. Apolos mampu berbicara dengan tepat, sesuai dengan permasalahannya, lengkap dan fasih mengenai hal apa pun.(Henry 1991) Apolos memiliki semangat dan sangat sungguh-sungguh dalam berkhotbah. Di dalam King James Version diterjemahkan "fervent in the spirit" atau "menyala-nyala di dalam Roh." Dengan sangat teliti ia mengajar (Yunani: akribōs) artinya teliti atau saksama, tepat. Semua yang dikatakan sudah dipertimbangkan baik-baik.(Strong 1990)

Namun dijelaskan di dalam Kis.18:25, bahwa Apolos hanya mengetahui baptisan Yohanes. Apolos hanya menerima pengajaran tentang Injil Kristus sejauh yang dibawakan oleh pelayanan Yohanes. Apolos belum memiliki kesempatan untuk berbincang-bincang dengan salah satu dari rasul sejak pencurahan Roh Kudus. Jadi ada kemungkinan Apolos sudah dibaptis hanya dengan baptisan Yohanes, tetapi belum dibaptis dengan Roh Kudus, seperti yang dialami oleh para rasul pada hari Pentakosta.(Henry 1991) Apolos berkhotbah di dalam rumah ibadat dan Akwila dan Priskila menemukan bahwa pengetahuan Apolos masih perlu dilengkapi. Priskila dan Akwila membawanya ke rumah mereka, dan menjelaskan kepada Apolos mengenai Jalan Allah dan jalan keselamatan melalui Yesus Kristus dengan teliti, yang di dalam King James Version memakai instilah "lebih sempurna" (KJV: more perfectly).

\section{Struktur Teks Kisah Para Rasul 18:1-4}

Struktur yang penulis pakai dalam penulisan ini diambil dari Hannah Bible Outline membuat struktur untuk teks ini lebih detail

Tent Making (Acts 18:1-4)

a. Paul's coworkers (Acts 18:1-3)

b. Paul's work ethic (Acts 18:3-4)(Hannah n.d.)

\section{Eksposisi Kisah Para Rasul 18:1-4}

Dalam kaitan dengan penulisan disertasi ini, penulis ingin menggunakan struktur teks dibuat oleh John Hannah pada teks Kisah Para Rasul 18:1-18 sebagai Model Bussiness For Kingdom seperti berikut:

\section{Tent Making (Kis.18:1-4)}

Di dalam struktur teks yang dibuat oleh John Hannah, Stage 1 ini memiliki dua bagian yaitu Paul's Co-workers dan Paul's Work Ethic yang akan penulis uraikan di bawah ini:

\section{a. Paul's Coworkers (Kis.18:1-3)}

\section{Kisah Para Rasul 18:1 "Dia meninggalkan Atena, lalu pergi ke Korintus"}

Letak kota Korintus sekitar 50 mil di sebelah barat Atena di negeri berlajur sempit (isthmus). Di Athena, Paulus tinggal seorang diri untuk sementara waktu di Korintus (lih. ay 5). Paulus tidak banyak mengalami perlakuan buruk seperti dianiaya atau dihalau di Atena, seperti yang dialaminya di tempat-tempat lain. Tetapi sikap dingin yang diterima di Atena, 
serta peluang untuk melakukan pelayanan yang sangat sedikit membuat Paulus meninggalkan Atena, dan pelayanan diserahkan kepada Dionisius. Kemudian Paulus pergi ke Korintus, tepatnya di Akhaya sebuah kota yang kaya dan megah yang adalah sebuah provinsi kekaisaran.(Henry 1991)

\section{Kisah Para Rasul 18:2 "Seorang Yahudi bernama Akwila. Priskila"}

Pada jaman gereja mula-mula, ada banyak contoh orang percaya yang mendedikasikan dan mengorbankan diri mereka untuk pelayanan bagi Allah yang kurang dikenal yang tanpanya para pemimpin ini tidak dapat mencapai apa yang mereka lakukan untuk Tuhan. Orang-orang ini sama-sama mengabdi dan berkorban untuk, pelayanan kepada Allah. Sesuai dengan konteks ayat yang sudah ditentukan, maka jelas bahwa orang-orang tersebut adalah pasangan Akwila dan Priskila.

Profil Akwila dan Priskila pertama kali diperkenalkan dalam Kisah Para Rasul 18. Mereka adalah tim suami-istri yang dinamis yang memainkan peran berharga dalam kehidupan Paulus dan di gereja mula-mula. Ayat 2 menyatakan bahwa Akwila dan istrinya, Priscilla, telah diusir dari Roma oleh dekrit Kaisar Claudius pada tahun 49 AD yang mengharuskan semua orang Yahudi untuk pergi dari Roma. Maka mereka menetap di Korintus, sebuah kota komersial besar, di mana mereka bertemu dengan Rasul Paulus. Pada saat itulah Allah membawa Akwila dan Priskila ke dalam kehidupan Paulus melalui profesi mereka bersama - membuat kemah. Pertemuan mereka di Korintus adalah awal dari hubungan seumur hidup dengan Paulus.(Bob 1996)

\section{Teladan Akwila dan Priskila}

Akwila dan Priskila yang berprofesi sebagai pedagang tenda yang melayani dapat dijadikan teladan karena:

\section{Memiliki Dedikasi Melayani Tuhan}

Akwila dan Priskila adalah bahwa mereka mengabdikan hidup mereka kepada Tuhan dan saudara-saudara, bergerak ke mana pun Tuhan mengarahkan mereka. Dalam teks ini, Akwila dan Priskila bekerja bersama Paulus di Korintus. Kemudian ketika Paulus meninggalkan Korintus ke Efesus, Akwila dan Priskila pindah bersamanya untuk membantu pekerjaan di sana (Kisah Para Rasul 18: 18-19). Dalam ayat 22-26 Akwila dan Priskila tetap tinggal di Efesus, bertemu dan membantu Apolos mendapatkan pemahaman yang lebih baik tentang Injil. (Henry 1991) Selanjutnya, pada saat Paulus menulis suratnya kepada orangorang Romawi, Akwila dan Priskila kembali ke Roma untuk membantu saudara-saudara di sana karena Paulus menyebut mereka di akhir suratnya, dengan mengatakan, "Sapa Priskila dan Akwila, para penolongku dalam Kristus Yesus." (Roma 16:3).

Ketika Paulus menyapa mereka di akhir Roma, ia mengucapkan terima kasih kepada mereka atas pengorbanan mereka yang dibuat untuknya secara pribadi (lih. Roma 16:4), Jadi, rupanya Akwila dan Priskila melayani semua gereja-gereja orang bukan Yahudi dengan cara tertentu. Akhirnya, Paulus menyebut mereka "penolongku" dalam Roma 16: 3. Gelar yang luar biasa untuk diberikan. Hanya ada sekelompok orang tertentu dalam Perjanjian Baru yang disebut Paulus sebagai pembantunya, atau rekan kerja. Hal ini memberikan indikasi betapa aktifnya Akwila dan Priskilla dalam pelayanan Tuhan.

Pelajaran penting yang dinyatakan melalui kehidupan adalah Dedikasi Kepada Tuhan. Fokus utama Akwila dan Priskila tidak pada karier duniawi mereka atau menjadi nyaman dalam kehidupan ini. Mereka melihat hidup mereka sebagai peziarah untuk melayani Tuhan, bergerak ke manapun dibutuhkan dan melakukan apa pun untuk memajukan pekerjaan Allah di bumi. Hal ini berbeda dengan kebanyakan para pebisnis Kristen pada masa kini, yang fokus pada urusan bisnis dan mengesampingkan pelayanan atau hanya melayani sesuai 
jadwal yang ditentukan saja. Sebagai orang percaya memiliki banyak kesempatan untuk menyerahkan hidup untuk melayani Tuhan dengan menggunakan waktu, energi, bakat, dan harta untuk membantu sesama orang percaya baik secara rohani, hospitality maupun ekonomi, seperti yang dikatakan oleh Rasul Paulus dalam Galatia 6: 9-10.

\section{Pelayanan Rohani dan Pelayanan Praktis}

Di dalam Kisah Para Rasul 18: 24-26 menjelaskan bahwa Akwila dan Priskila turut andil di dalam pelayan rohani yaitu dengan memuridkan Apolos. Apolos rupanya sudah diselamatkan di bawah sistem Perjanjian Lama, tetapi kurang dalam pemahamannya mengenai karya Kristus di kayu Salib dan pekerjaan Roh Kudus dalam kehidupan orang percaya. Akwila dan Priskila menyadari bahwa Apolos membutuhkan lebih banyak landasan dan pemuridan lebih lanjut. Akwila dan Priskila peka terhadap kebutuhan Apolos untuk memperoleh penjelasan yang lebih lengkap mengenai Tuhan Yesus.(Henry 1991)

Pelayanan Akwila dan Priskila kepada Tuhan dan saudara-saudara melalui apa yang mereka miliki diwujudkan dengan cara yang sangat istimewa yaitu menyambut atau menerima dan melayani orang lain di rumah mereka. Dua kali, Paulus menutup suratsuratnya dengan salam kepada Akwila dan Priskila dan gereja yang ada di rumah mereka, seperti di dalam Roma 16: 3-5, dan 1 Korintus 16:19.

Kesediaan untuk membuka rumah mereka kepada orang lain adalah bukti kasih mereka kepada Tuhan, dan kesediaan untuk menggunakan semua milik mereka untuk melayani Tuhan. Akwila dan Priskila menginjinkan rumah mereka dipakai untuk pelayanan. Suatu cara yang menarik untuk terlibat dalam pekerjaan Tuhan: dengan menggunakan rumah atau harta milik yang telah Tuhan berikan untuk kemuliaan Allah. Paulus memberi tahu orangorang Romawi bahwa mereka harus "diberi keramahtamahan." (Roma 12:13).

\section{b. Paul's Work Ethic (Kis. 18:3-4)}

Bagian ini dapat dibagi dalam dua bagian, yaitu:

\section{Kisah Para Rasul 18:3 "karena mereka sama-sama tukang kemah".}

Kata tukang kemah biasa dikenal dengan pembuat kemah, namun kata tukang kemah

bisa juga ditujukan bagi pekerjaan penyamak kulit. Kilikia, daerah asal Paulus, terkenal karena bulu dan kulit kambing. Latar belakang Paulus sebagai rabi menuntutnya untuk memiliki pekerjaan sekuler, karena tidak ada rabi yang dibayar untuk mengajar.(Bob 1996)

Pembuat tenda atau tent-maker (Yunani: skenopoios) hanya disebutkan satu kali (Kisah 18: 3).(Strong 1990) Definisi mengenai tent-maker merupakan metode strategis yang Tuhan gunakan di bagian dunia tertentu. Misionaris pembuat kemah datang dalam beberapa variasi. Karena dibutuhkan semua jenis pelayanan untuk menjangkau dunia ini bagi Kristus, sepertinya Tuhan telah memberi banyak kebebasan dalam gaya, metode, dan kombinasi, yang merupakan keindahan tent-maker. Namun, itu akan lebih baik untuk menggunakan strategi tent-maker Paulus sebagai contoh(White 2012) Istilah "pembuat tenda" sebagai

orang Kristen yang berkomitmen pada misi yang mendukung diri mereka sendiri di luar negeri, dan membuat Yesus Kristus dikenal di waktu luang mereka. Mereka di pelayanan sepenuh waktu bahkan ketika mereka memiliki pekerjaan penuh waktu, karena mereka menggabungkan pekerjaan dan kesaksian. Mereka mengikuti model tent-maker Paulus, dan untuk alasan yang sama.(Siemens 1997)

Dalam zaman Perjanjian Baru ada kebiasaan untuk mengajarkan setiap anak laki-laki Yahudi mengenai perdagangan. Paulus mempraktikkan hal perdagangan ini bersama Priskila dan Akwila di Korintus (Kis 18: 1-3). Hal ini terlihat dengan jelas tentang jenis kehidupan yang dijalani Paulus. Dia adalah seorang rabi dan menurut praktik Yahudi setiap rabi harus 
memiliki perdagangan. Dia tidak boleh mengambil uang untuk berkhotbah dan mengajar dan harus mencari nafkah sendiri.(Barclay n.d.) Orang Yahudi memiliki kebiasaan mengajari anak-anaknya untuk berdagang. Orang yang tidak mengajari anaknya berdagang seolah-olah mengajari anaknya untuk menjadi pencuri. Orang Yahudi memuliakan pekerjaan. Orang tua yang tidak mengajar putranya berdagang, mengajarinya perampokan.(Barclay n.d.) Biarpun Paulus adalah seorang Farisi dan dibesarkan dan diajarkan oleh Gamaliel, namun sejak muda dia telah belajar membuat kemah.(Henry 1991)

Sekalipun Paulus seorang yang terdidik dan terpelajar, namun dia memiliki kemampuan untuk melakukan usaha dagang dengan kerajinan tangan yaitu membuat tenda. Paulus yang tidak menuntut agar dipenuhi segala kebutuhannya oleh jemaat, sekalipun jemaat mengetahui bahwa Paulus sedang mengalami kesulitan. Paulus sangat rendah hati dan mau belajar dari Tuhan-nya, yang datang bukan untuk dilayani, melainkan untuk melayani. Hal ini menunjukkan bahwa Paulus adalah seorang yang mandiri, rajin dan bersedia berusaha. Paulus dapat memiliki banyak pekerjaan yang luar biasa dengan pikirannya, namun dia tidak menganggap dirinya terlalu tinggi untuk bekerja dengan tangannya.(Henry 1991) Ini merupakan pelajaran berharga bagi hamba Tuhan atau para pelayan masa kini untuk tidak menuntut hak atau "berdoa di telinga" sponsor atau jemaat, tetapi mau berdoa dan bekerja.

Paulus sangat hati-hati supaya dirinya dan pelayanannya dapat diterima. Sikap ini untuk mencegah prasangka buruk terhadap pelayanannya, sehingga dia melakukan pekerjaan untuk menghidupi dirinya ,supaya dia tidak menjadikan Injil Kristus beban (2 Korintus 11:9; 2 Tesalonika 2:9; 3:8-9).(Barclay n.d.) Di dalam Kis.18:3 mencatat alasan mengapa Paulus membuat tenda dan bagaimana strategi misinya membuat keuntungan pelayanannya.(White 2012) Paulus mengerjakan pekerjaan sementaranya itu bersama Akwila dan Priskila dan mendapatkan upah harian yang hanya cukup untuk memenuhi kebutuhan hidup yang paling sederhana. Tindakan Paulus untuk membuat tenda ini hanya sebagai jalan keluar sementara karena desakan untuk memenuhi kebutuhannya, setelah itu pada bagian lain tidak ditemukan lagi Paulus bekerja untuk kebutuhannya. Paulus hanya fokus pada pelayanannya saja.(Henry 1991) Hal ini tentunya patut untuk diteladani oleh hamba Tuhan untuk tidak kebablasan berbisnis sehingga melupakan panggilan mula-mula, yaitu untuk melayani Tuhan.

Berkaca pada motivasi Paulus dalam memenuhi kebutuhan ekonomi, hendaknya bisnis hanya dijadikan sebagai usaha sementara dan tetap fokus pada pelayanan yang merupakan tanggung jawabnya. Seorang rasul besar seperti Paulus, namun dia memilih untuk bekerja bersama Akwila dan Priskila (ay. Kis 18:26). Dan dia mengakui bahwa mereka telah menjadi "teman-teman sekerjaku dalam Kristus Yesus" (Rm. 16:3).(Bob 1996) Paulus tidak bergantung pada jemaat atau orang lain dalam menunjang kebutuhannya dan Paulus juga tidak memanipulasi pelayanannya untuk mendapatkan uang, namun perlu dicatat bahwa Paulus hanya menggunakan ketrampilan atau kemampuan yang untuk berbisnis secara temporer.

\section{Kisah Para Rasul 18:4 "Setiap hari Sabat Paulus berbicara dalam rumah ibadat"}

Setiap hari Sabat, Paulus aktif "mengajar" dan "berusaha meyakinkan" (keduanya imperfect tense artinya mengajar dan berusaha meyakinkan itu sedang berlangsung pada masa lampau). Paulus pergi ke orang-orang Yahudi lebih dulu karena mereka mengetahui Perjanjian Lama dan itu adalah teladan Yesus (lih. Mat. 10:5-6). Di sana juga ada orangorang Yunani yang takut akan Allah yang sangat meresponi pemberitaannya (lih.Rom 1:16).(Bob 1996) Pada setiap hari Sabat, Paulus berbicara secara terang-terangan kepada mereka dalam rumah ibadat. Hal ini merupakan cara rasul-rasul menyebarkan Injil, bukan dengan kekuatan dan kekerasan, tidak menuntut orang untuk sepenuhnya setuju, melainkan dengan berdebat secara adil.(Henry 1991) Dia berusaha meyakinkan mereka - (Yunani: epeithe). Ini menunjukkan bahwa, ada perbedaan pemahaman antara Paulus dan para 
pendengarnya, namun Paulus dapat memberikan alasan-alasannya dengan penuh kasih. Paulus memengaruhi mereka sehingga menerima pandangannya. Beberapa di antara mereka diyakinkan oleh Paulus dan menyerahkan diri kepada Kristus.(Henry 1991)

\section{Model Business For Kingdom}

Melalui uraian dari struktur teks Kisah Para Rasul 18:1-4 ini, penulis mendapatkan Model Business For Kingdom sebagai berikut:
A. Sebagai Pendukung Pelayanan (Co-Worker)
1. Melayani Bersama
2. Berdedikasi Kepada Tuhan
3. Pelayanan Rohani (Memuridkan)
4. Pelayanan Praktis (Dengan Apa Yang Dimiliki)

\section{B. Sebagai Pelayan atau Hamba Tuhan (Work Ethic)}

1. Mandiri. Bekerja untuk memenuhi kebutuhan hidupnya

2. Tidak Menuntut. Karena jabatan sebagai Rasul

3. Rendah Hati. Bukan untuk dilayani, melainkan untuk melayani.

4. Maksimal. Membuat Tenda dan Berkhotbah (pelayanan rohani)

\section{METODE PENELITIAN}

Penelitian ini adalah penelitian kualitatif deskriptif dengan pendekatan literature research, eksposisi dan wawancara untuk memperoleh gambaran kondisi pelayan Tuhan di Sinode Gereja Kristen Parousia yang melakukan pelayanan full-time dan juga berbisnis. Peneliti juga melakukan studi ekspositoris karena mengemukakan prinsip-prinsip di dalam teks Kisah Para Rasul 18:1-4 dengan menggunakan Alkitab sebagai sumber dan literaturliteratur yang yang mendukung tema yang sudah peneliti tentukan.

Penulis, dalam hal ini sebagai instrumen utama harus memiliki wawasan yang luas sehingga mampu bertanya, menganalisa, dan merekonstruksi situasi sosial yang diteliti menjadi lebih jelas Penelitian kualitatif juga dimaksudkan untuk melakukan penelitian yang terinci dan mendalam, mendapat data-data literatur, serta dokumen-dokumen Sinode Gereja Kristen Parousia. secara komprehensif. Observasi partisipan atau informan dilakukan untuk memperoleh informasi dari sumber data primer yang dikumpulkan oleh peneliti langsung dari sumber utama yaitu beberapa informan terpilih dari Sinode Gereja Kristen Parousia.

Pada tahap awal, sampel sumber data saat penelitian adalah dengan memilih orangorang yang memiliki otoritas pada situasi atau obyek yang diteliti, supaya menjadi pintu atau jalan masuk kemana saja untuk peneliti memperoleh data. Tujuan dari cara ini adalah supaya validitas sampel dan data lapangan tidak terbantahkan. Instrumen penelitian wawancara dan terpilih dengan model wawancara terbuka untuk mendapatkan informasi yang objektif dan akurat.

Dalam penelitian ini, peneliti memiliki asumsi yang berguna untuk membangun, mengembangkan dan mempertahankan teori serta prinsip-prinsip Model Business For Kingdom Berdasarkan Kisah Para Rasul 18:1-4 Dalam Mengembangkan Sinode Gereja Kristen Parousia, sebagai berikut:

1. Bisnis bukan hanya sebagai aktivitas kerja tapi juga pelayanan

2. Business for Kingdom dapat menjadi salah satu alternatif dalam pengembangan pelayanan misi dan perintisan gereja yang mempertobatkan, mencerdaskan, memberdayakan dan mensejahterakan.

Teknik pengumpulan data adalah wawancara yaitu peneliti melakukan wawancara langsung kepada pelayan Tuhan di Sinode Gereja Kristen Parousia dan pengurus Sinode Gereja Kristen Parousia. Peneliti mendapatkan informasi yang lengkap tentang kapasitas mereka dalam menjalankan pelayanan dan bisnis. Selain teknik wawancara, kami juga 
melakukan pengumpulan data melalui kegiatan observasi dan dokumentasi aktifitas pelayan Tuhan di Sinode Gereja Kristen Parousia.

Selanjutnya, peneliti juga telah melakukan diskusi dan pertemuan dengan pelayan Tuhan guna menggali informasi tentang aktifitas dan usaha mereka. Pertemuan dan diskusi berlangsung secara intensif. Melalui pertemuan dan diskusi tersebut, kami mendapatkan informasi yang mendukung data-data hasil wawancara sebelumnya. Penelitian ini dilakukan selama empat bulan yakni mulai bulan Februari hingga Juni 2020 dan mendapatkan datadata penelitian, baik data primer maupun data sekunder.

Data-data tersebut dianalisis melalui pendekatan pendekatan (Creswell 2014) yakni, manajemen data (mengorganisasikan) mentoring data, refleksi dan menulis catatan, deskripsi, klasifikasi dan penafsiran data (kategori dan perbandingan data), penyajian dan visualisasi data. Berangkat dari masalah tersebut, kami mendesain model Business for Kingdom, yaitu

1. Man of God

2. Mission Purpose

3. Message of God

4. Management

5. Method

6. Mentoring

Sinergisitas keenam aspek tersebut dipercayai mampu mewujudkan Business for Kingdom dalam mengembangkan Sinode Gereja Kristen Parousia

\section{HASIL DAN PEMBAHASAN}

Hasil analisis data menunjukkan bahwa terdapat beberapa masalah yang dihadapi oleh pelayan Tuhan dalam pelayanan dan usaha bisnis, yaitu Pertama, Belum memahami bagaimana cara membagi waktu antara bisnis dan pelayanan. Kedua, Ada kekuatiran terhadap fokus dan motivasi pelayanan yang tidak lagi mengutamakan pelayanan tetapi pada bisnis. Ketiga, Hanya menjalankan bisinis dan pelayanan secara sederhana dengan arahan pendamping dan masih terbatas dalam strategi dan manajemen bisnis. Keempat, Belum memiliki sistem dan model bisnis yang spesifik. Masalah-masalah tersebut dipandang sebagai bagian dari persoalan krusial yang menghambat majunya pelayanan dan juga bisnis yang sedang dijalankan.

\section{Masalah-Masalah}

1. Belum memahami bagaimana cara membagi waktu antara bisnis dan pelayanan.

Hasil penelitian ini menunjukkan bahwa kendala utama yang dihadapi oleh para pelayanan yang melayani Tuhan sambal berbisnis adalah waktu. Berdasarkan data wawancara yang dihimpun menunjukkan bahwa pelayanan kepada Tuhan sambal melakukan bisnis belum dijalankan dengan manajemen bisnis yang baik.

Tentu saja, usaha ini berdampak langsung pada lambatnya perkembangan usaha yang ditekuni. Waktu merupakan hal yang sangat krusial dan perlu untuk diatur dengan baik sehingga tidak ada pelayanan atau pekerjaan yang terbengkalai. Bisnis yang dipercayakan Tuhan harus dijalankan dengan sebaik-baiknya karena sekalipun bisnis merupakan prioriotas ke dua, seorang hamba Tuhan tersebut hendaknya profesional dalam menjalankan bisnisnya karena bisnis adalah milik TuhanAda kekuatiran terhadap fokus dan motivasi pelayanan yang tidak lagi mengutamakan pelayanan tetapi pada bisnis. (Tan 2010)

\section{Ada kekuatiran terhadap fokus dan motivasi pelayanan yang tidak lagi mengutamakan pelayanan tetapi pada bisnis}


Dari penelitian yang dilakukan, peneliti menemukan bahwa ada kekuatiran dalam pelayanan sembari berbisnis, yaitu: focus dan motivasi pelayanan yang berubah misalnya: tidak lagi memprioritaskan pelayanan tetapi beralih pada bisnis.

Seorang hamba Tuhan yang menjalankan pelayanan dan bisnis harus ada keseimbangan. Memang kedua bidang yang dilakukan adalah pemberian yang Tuhan percayakan, tetapi harus senantiasa memprioritaskan pelayanan sebagai yang utama. Seorang hamba Tuhan harus melakukan untuk kemuliaan Tuhan karena bisnis itu adalah milik Tuhan dan manusia hanya sebagai pengelola saja. Bisnis harus dilihat sebagai alat bukan tujuan. Orang Kristen hendaknya memahami bahwa bisnis hanya memiliki fungsi sebagai alat agar hidup manusia dapat terpelihara. Bisnis bukanlah segalanya dan tidak boleh menjadi tujuan hidup manusia. Hal ini sudah dilakukan oleh Rasul Paulus, yaitu dengan berjualan tenda sebagai alat untuk mendukung pelayanan dan kebutuhan hidupnya tanpa membebani kehidupan keuangan jemaat. (Kis.18:1-3)(Stamps 1995).

\section{Hanya menjalankan bisinis dan pelayanan secara sederhana dengan arahan pendamping dan masih terbatas dalam strategi dan manajemen bisnis.}

Berdasarkan hasil wawancara dan diskusi mendalam melalui pertemuan informal antara peneliti dan para pelayan Tuhan menunjukkan bahwa pekerja atau pelayan Tuhan belum memiliki wawasan yang cukup tentang strategi dan manajemen bisnis.

Bisnis yang Tuhan percayakan harus dijalankan secara bertanggungjawab. Walaupun bisnis bukan yang prioritas bagi seorang hamba Tuhan, tetapi hendaknya bisnis dapat dijalankan secara profesional karena bisnis adalah milik Tuhan. (Tan 2010) Setiap keputusan, strategi dan kebijakan harus disaring melalui seperangkat aturan yang diterapkan sendiri yang disebut nilai-nilai alkitabiah. Setiap tujuan dan sasaran harus mencapai tujuan ilahi. Bahkan prosesnya harus memuliakan Tuhan dan tujuan tidak harus membenarkan cara(How n.d.)

\section{Belum memiliki sistem dan model bisnis yang spesifik}

Berdasarkan temuan analisis data, baik secara umum maupun secara khusus, maka dalam bagian ini, peneliti menawarkan suatu pola atau model bisnis yang dapat digunakan dalam pelayanan di Sinode Gereja Kristen Parousia ataupun dalam pelayanan di tempat lain. Model Business For Kingdom yang peneliti tawarkan adalah 6M yaitu:

\section{Man of God}

Seorang manusia Tuhan adalah seorang yang berkomitmen sepenuhnya kepada Tuhan. Kitab suci mendefinisikan secara ringkas mengenai manusia Allah adalah Mikha 6: 8, yang menyatakan,"Hai manusia, telah diberitahukan kepadamu apa yang baik. Dan apakah yang dituntut TUHAN dari padamu: selain berlaku adil, mencintai kesetiaan, dan hidup dengan rendah hati di hadapan Allahmu?" Untuk dapat "berjalan dengan rendah hati" kepada Allah, seseorang harus memiliki hati yang mengikuti hati Allah sendiri seperti Daud (Kisah Para Rasul 13:22) dan harus mematuhi perintah-perintah-Nya. Satu-satunya syarat untuk menjadi manusia Allah adalah memiliki hati yang selaras dengan hati Allah. Kemudian, abdi Allah akan dibentuk oleh Tuhan untuk menjadi dan untuk melakukan apa yang Tuhan inginkan.

Menjadi manusia Tuhan adalah hal sederhana yang sangat sulit karena membutuhkan ketundukan total kepada Tuhan, yang bertentangan dengan kodrat kemanusiaan yang telah jatuh dalam dosa. Manusia tidak bisa melakukannya dengan kekuatan sendiri. Seseorang disebut sebagai manusia Tuhan apabila ia menyerah kepada Tuhan dan mengizinkanNya untuk mengubah hatinya menjadi apa yang Dia inginkan. Maka orang itu akan benar-benar mencari dahulu kerajaan Allah dan berjalan dengan rendah hati dengan Allah. Jadi, Seorang manusia Tuhan yang peneliti maksudkan bagi Model Business For Kingdom adalah:

i. Sudah bertobat dan Lahir Baru

ii. Memiliki panggilan Tuhan untuk melayani. 
iii. Berkomitmen sepenuhnya bahwa bisnis yang dilakukan adalah untuk Tuhan.

iv. Mengutamakan Tuhan dalam segala hal, sehingga pembacaan Alkitab, renungan pribadi, doa adalah sebuah keharusan

v. Rendah hati

\section{Mission Purpose}

Fokus pelayanan atau bisnis dan bahkan hidup adalah fokus Kerajaan Allah alih-alih duniawi. Kolose 3: 2 - "Tentukan pikiranmu pada hal-hal yang di atas, bukan pada hal-hal yang ada di bumi." Dengan memiliki fokus misi bagi Kerajaan Allah akan memengaruhi cara seseorang memandang pekerjaan itu sendiri, cara seseorang memandang uang, dan cara memperlakukan orang lain dengan kasih.

\section{Message of God}

Berita yang harus disampaikan terdapat di dalam 1 Kor 15:1-19 bahwa Yesus Kristus yang adalah Allah, yang menjadi manusia, menderita dan mati, dikuburkan, tetapi bangkit dari antara orang mati untuk menebus manusia dari dosa.

Berita yang sangat penting adalah bahwa Yesus bangkit dari kematian; bahwa ada kebangkitan orang mati karena Yesus melakukannya. Jika Yesus tidak hidup lagi, Kekristenan hanya akan menjadi bohong. Jika Yesus tidak bangkit dari kematian, pada ayat 14 menyatakan bahwa Alkitab itu omong kosong dan iman orang Kristen tidak berguna. Jika Yesus tidak bangkit dari kematian, ayat 15-19 memaparkan bahwa orang percaya adalah sekelompok pembohong. Pada ayat 20 tertulis, Kristus memang telah dibangkitkan dari kematian, kebangkitan Yesus Kristus adalah segalanya bagi orang percaya. Ini adalah berita yang sangat penting yang harus dinyatakan pada dunia ini. Karena Yesus hidup (ayat 2024).

\section{Management}

Dalam hal management, perlu untuk memperhatikan kerapihan administrasi dan senantiasa jujur dalam hal keuangan. Mengelola uang sebagai milik Allah. Dengan melihat keuangan bisnis sebagai milik Allah, akan memberi perspektif yang baik tentang bagaimana menangani berbagai hal. Bekerja dalam bisnis Tuhan dan menangani uang Tuhan sehingga apa yang diakukan menjadi penting dan harus ditangani dengan penuh kesetiaan dan tanggung jawab.

Tidak salah menghasilkan uang, tetapi akan menjadi salah apabila lebih cinta uang. Ibrani 13: 5 menyatakan bahwa, "Jaga hidupmu bebas dari cinta uang, dan puaslah dengan apa yang kamu miliki, karena dia berkata," Aku tidak akan pernah meninggalkanmu atau meninggalkanmu. "Sehingga pelayan atau hamba Tuhan harus mau bekerja tanpa terobsesi dengan uang atau kekayaan.

\section{Method}

Metode yang peneliti ajukan didasarkan Kisah Para Rasul 18:1-4

a. Sebagai Pendukung Pelayanan (Co-Worker)

1) Melayani Bersama

2) Berdedikasi dan Antusias Kepada Tuhan

3) Pelayanan Rohani (Memuridkan)

4) Pelayanan Praktis (Dengan Apa Yang Dimiliki)

b. Sebagai Pelayan atau Hamba Tuhan (Work Ethic)

1) Mandiri. Bekerja untuk memenuhi kebutuhan hidupnya

2) Tidak Menuntut. Karena jabatan sebagai pemimpin jemaat 
3) Rendah Hati. Bukan untuk dilayani, melainkan untuk melayani.

4) Maksimal. Pelayanan dan bisnis

Sangat penting bagi hamba Tuhan untuk tidak putus asa dalam upaya bisnis. Untuk itu, pelayanan Business For Kingdom harus dilakukan dengan tulus dan penuh kasih. Pemasaran dilakukan strategis tetapi tidak busuk. Karena ada banyak hal yang dapat dilakukan dalam pemasaran yang legal dan jujur, tetapiada juga yang melakukannya dengan tidak jujur. Di dalam pelayanan Business For Kingdom, harus didasari dengan tanggung jawab bukan saja pada diri sendiri atau mentor/sinode tetapi pada Tuhan. Untuk itu, sangat ditekankan untuk mempromosikan produk atau layanan dengan jujur.

Pelayanan Business For Kingdom harus memperlakukan pelanggan sebagai orangorang yang diciptakan menurut gambar Allah, bukan hanya sebagai sarana untuk mencapai tujuan. Setiap orang yang berinteraksi harus diperlakukan dengan bermartabat dan hormat, karena mereka diciptakan menurut gambar Allah. Bisnis tidak harus berbasis iman untuk menjadi efektif atau menjadi ladang pelayanan. Karena apabila hanya melayani pembeli Kristen, maka pelayan atau pekerja sebenarnya telah kehilangan kesempatan untuk melayani orang-orang yang mungkin tidak mengenal Tuhan.

\section{Mentoring}

- Relasi

- Komunikasi

- Visitasi

- Persekutuan

\section{SIMPULAN}

Paulus mengerjakan pekerjaan sementara melakukan pelayanannya: Dia bekerja bersama Akwila dan Priskila dan mendapatkan upah harian yang hanya cukup untuk memenuhi kebutuhan hidup yang paling sederhana. Tindakan Paulus untuk membuat tenda ini hanya sebagai jalan keluar sementara karena desakan untuk memenuhi kebutuhannya, setelah itu pada bagian lain tidak ditemukan lagi Paulus bekerja untuk kebutuhannya. Selanjutnya, Paulus hanya fokus pada pelayanannya saja.

Sinode Gereja Kristen Parousia merekrut hamba Tuhan yang searah dengan visi misi Sinode, salah satunya hamba Tuhan harus melakukan bisnis, usaha kecil, uang menunjang kebutuhan hidup dan pelayanan tetapi juga memberdayakan dan mensejaterahkan jemaat. Jadi hamba Tuhan yang bergabung dengan Sinode Gereja Krsiten Parousia adalah yang setuju bahwa hamba Tuhan akan melakukan bisnis lewat usaha kecil.

Dalam pelaksanaanya perlu melihat Man of God, dalam artian hamba Tuhan yang memiliki panggilan pelayanan penuh waktu dan berkomitmen terhadap Tuhan melalui visi misi Sinode. Hamba Tuhan juga perlu konsisten terhadap tujuan misi (Mission Purpose) agar tetap menjadi alat Tuhan yang mewartakan berita keselamatan dan kebangkitan Tuhan Yesus Kristus (Messege of God), yang dalam perjalanannya mengutamakan pelayanan dan usaha kecil adalah alat untuk mendukung pelayananannya. Menjalankan dengan seimbang antara pelayanan dan usaha kecil, perlu Method yang tepat, dan ada dalam System Management yang telah ditetapkan oleh Sinode serta menerima dengan baik Mentoring yang akan dijalankan. Dengan demikian hamba Tuhan penuh waktu dalam Sinode Gereja Kristen Parousia akan bisa melakukan pelayanannya dengan maksimal serta menjalankan misi Usaha Kecil dengan baik.

\section{DAFTAR PUSTAKA}

Alteza, Muniya. 2011. Pengantar Bisnis: Teori Dan Aplikasi Di Indonesia. Yogyakarta: Fakultas Ilmu Sosial Ekonomi Universitas Negeri Yogyakarta. 
Anggraini, Dewi dan Nasution, Syahrir Hakim. 2013. "Peranan Kredit Usaha Rakyat (KUR) Bagi Pengembangan UMKM Di Kota Medan (Studi Kasus Bank BRI).” Ekonomi Dan Keuangan Vol.1.No (:105.

Anon. n.d. "Bisnis." Retrieved November 20, 2019 (https://id.wikipedia.org/wiki/Bisnis). Barclay, William. n.d. "Bible Commentaries William Barclay's Daily Study Bible. Acts 18."

Retrieved November 26, 2019 (https://www.studylight.org/commentaries/dsb/acts18.html).

Bob, Utley. 1996. "Pengantar Kepada Kisah Para Rasul.” East Texas: Baptis University. Boone, Louis E dan Kurtz, David L. 2002. Pengantar Bisnis. Jilid Ke-1. Jakarta: Penerbit Erlangga.

Burton, David W. Hall \&. Matthew D. 2019. Calvin Dan Perdagangan. Surabaya: Penerbit Momentum.

Calvin, John. 1979. Commentaries on the Epistles to the Philippians, Collosians, and Thessalonians. Grand Rapids: Baker Book House.

Creswell, John W. 2014. Research Design Pendekatan Kualitatif, Kuantitatif, Dan Mixed. Yogyakarta: Pustaka Pelajar.

Deffinbaugh, Bob. n.d. "'Seeing Paul in Perspective (Acts 18:1-19:7)." Retrieved

November 24, 2019 (https://bible.org/series/studies-book-acts).

Frame, John M. 2008. The Doctrine of the Christian Life. Phillipsburg, NJ: P \& R Pub.

Hannah, John. n.d. "Hannah Bible Outline." Retrieved November 20, 2019 (https://www.preceptaustin.org/acts-18-commentary,).

Henry, Mathhew. 2008. Injil Matius. Jilid 2. Surabaya: Penerbit Momentum.

Henry, Matthew. 1991. Henry, Matthew Henry's Commentary on the Whole Bible. Complete and Unabridged in One Volume. USA: Hendrickson Publisher, Inc.

Hidayah, Dewi Meisari Haryanti dan Isniati. 2018. "Potret UMKM Indonesia: Si Kecil Yang Berperan Besar." Retrieved November 23, 2019 (https://www.ukmindonesia.id/baca$\operatorname{artikel/62).~}$

Hill, Alexander. 2001. Bisnis Yang Benar. Bandung: Kalam Hidup.

How, Tan Seow. n.d. "'My Journey to Becoming BOTH a Pastor and Businessman."” Retrieved (https://pastorhow.com/tanseowhow).

I. D. K. R. Ardina, I. A.Brahmayanti, \&. S. Subaedi. 2010. "Kompetensi SDM UKM Dan Pengaruhnya Terhadap Kinerja UKM Di Surabaya." Jurnal Manajemen Dan Kewirausahaan 12(1):42.

J.l. Packer, Merrill C. Tenney dkk. 2001. Ensiklopedia Fakta Alkitab Bible Almanac-1. Malang: Gandum Mas.

McCarty, K. V. 2012. "Prisca - Fellow Tent-Maker and Fellow Missionary of Paul: Acts 18.2-3, 18, 26; Romans 16.3-4; 1 Corinthians 16.19; 2 Timothy 4.19.” International Congregational Journal Vol. 11(2):p45-60. 16p.

Nyoto. 2019. Buku Ajar Manajemen Sumber Daya Manusia. Ponorogo: Uwais Inspirasi Indonesia.

Piper, John. 2019. Living in The Light. Money, Sex \& Power. Jakarta: Imanuel.

Ruffner, Brian E. 2004. A Theology Of Business: A Reformed Perspective On The Basis And Application Of Christian Ethics In Business. Charlotte, North Carolina: University of Pittsburgh.

Sandison, George. 2013. Bible Answers for 1000 Difficult Questions. Terj. Malang: Gandum Mas.

Saydam, Gouzali. 2006. Manajemen Sumber Daya Manusia (Human Resource) Suatu Pendekatan Mikro. Jakarta: Djambatan.

Setiawan, Joko. n.d. Pengantar Manajemen \& Bisnis. City: Module Kuliah Akademi Akuntansi Permata Harapan Batam.

Siemens, Ruth E. 1997. "The Vital Role of Tentmaking in Paul's Mission Strategy." 
INTERNATIONAL JOURNAL OF FRONTIER MISSIONS VOL 14(3).

Stamps, Donald C., ed. 1995. Alkitab Penuntun Hidup Berkelimpahan. Terj. Malang: Gandum Mas.

Stastistik, Data Badan Pusat. 2016. "Data Badan Pusat Stastistik BPS Indonesia Dalam Angka." Retrieved November 23, 2019 (https://www.bps.go.id/linkTabelSt atis/view/id/1322).

Stoner, James A. F. 1982. Management. Englewood Cliffs, New York: Prentice Hall International, Inc.

Strong, James. 1990. The New Strong's: Exhaustive Concordance Of The Bible. Nashville, Tennessee: Nelson.

Tan, Elsan. 2010. Siapa Bilang Pengusaha Bukan Hamba Tuhan. Light Publishing. Thayer, Joseph H. 1997. Thayer's Greek-English Lexicon of The New Testament. Michigan: Grand Rapids.

White, Chris. 2012. "The Father's Businessperson The Shift To Tentmaking Missions Strategy." Liberty Theological Seminary.

White, Jerry dan Mary. 1980. Bekerja. Jakarta: BPK. Gunung Mulia.

Wibowo, Sampurno. 2009. Pengantar Manajemen Bisnis. Bandung: Politeknik Telkom Telkom Poolitechnic.

Yaghoobi, Salarzehi, Aramesh \&. Akbari. 2010. "An Evaluation of Independent Entrepreneurship Obstacles in Industrial SMEs." European Journal of Social Sciences 33-45.

Zuck, Roy B., ed. 2010. A Biblical of Theology The Old Testament. Terj. Malang: Gandum Mas. 